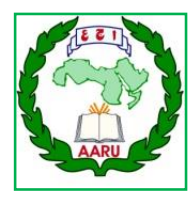

Arab Univ. J. Agric. Sci., Ain Shams Univ., Cairo, Egypt

28(4), 1077-1088, 2020

Website: http://ajs.journals.ekb.eg

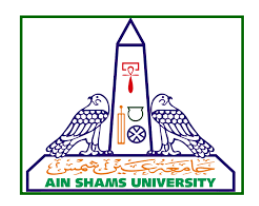

1077

\title{
Development of a Small-Scale Electromechanical Mobile Fish Feeder
}

\author{
Rashad A Hegazy*, Atef M Elsbaay, Mona M Kasem \\ Agric. Engineering Dept, Fac of Agric, Kafrelsheikh Univ, Kafrelsheikh, P.O. Box. 33516, Egypt \\ ${ }^{*}$ Corresponding author: rashad.hegazy@agr.kfs.edu.eg
}

Received 23 August, 2020

Accepted 1 November, 2020

\section{Abstract}

The aim of the present study was to develop and test a simple small-scale electromechanical mobile fish feeder to control feeding inside fish ponds. Fish feeder spreader consists of a solid frame, fish feed hopper, distributing disc with spreading fins, transmission system and electrical components. The electrical components include the rotational speed motor, distribution switch box, battery, dosage bar release motor, and transmission system DC brushed motors. Analysis and evaluation of distribution pattern of fish feed done under two different spreading disk rotational speeds of 1000 and 1250 rpm (17.3 and $21.6 \mathrm{~ms}^{-1}$ ), two feed outlet control slide settings for fish feed rate and three different fish feed types. The developed prototype can achieve 4.9 and $5.8 \mathrm{~kg} / \mathrm{min}$ distribution rate of fish feed type 1 (sizes from 1 to $2 \mathrm{~mm}$ and average bulk density of $530 \mathrm{~kg} \mathrm{~m}^{-3}$ ) under two distribution disc rotational speed of $1000 \mathrm{rpm}$ and $1250 \mathrm{rpm}$ respectively. Variation on distribution of feed material type 1 in both sides of the developed prototype was 8.4 and $14.7 \%$ for disk rotational speed $1000 \mathrm{rpm}$ and $1250 \mathrm{rpm}$ respectively with at most good distribution pattern. Feed distribution uniformity for feed type 2 (sizes from 2 to $3 \mathrm{~mm}$ and average bulk density of $720 \mathrm{~kg} \mathrm{~m}^{-3}$ ) was much better compare to the distribution pattern of feed type. Where, there was variation on distribution of feed material type 2 in both sides of the developed prototype by 3.5 and $3.11 \%$ for disk rotational speed $1000 \mathrm{rpm}$ and $1250 \mathrm{rpm}$ respectively under outlet slide settings 2 . Even with outlet slide settings 2 (only half of the outlet opening), distribution of feed material type 2 in both sides of the developed prototype was better and recorded 2.21 and $2.61 \%$ for disk rotational speed $1000 \mathrm{rpm}$ and $1250 \mathrm{rpm}$ respectively. Using fish feed material
\end{abstract}

with size bigger than $3 \mathrm{~mm}$ will lead to uneven distribution using current developed prototype.

Keywords: Aquaculture, Fish feeder system, Wear characteristics, Feeding rat, Distribution pattern

\section{Introduction}

Aquaculture is a globally important industry that provides essential food to a growing world population, Globally, Egypt ranks $9^{\text {th }}$ in fish farming production and $1^{\text {st }}$ among African countries (FAO 2018). In Egypt, the aquaculture is practiced in different production systems including semi-intensive, intensive culture in ponds, tanks, intensive production in cages and traditional extensive production systems. Semi-intensive aquaculture in earthen ponds is by far the most important fish farming system in Egypt, where 729,921 tonne, about $86 \%$ of aquaculture production, is obtained from these systems (Soliman and Yacout 2016).

Every fish farmer's primary objective is to rear the fish as quickly and healthily as possible. For optimum growth, it is vital that the fish are fed continuously and regularly. These factors are important in determining water quality and feed conversion rates (Linn 2020). Current developments in production are centred on the application of modern technologies and are a result of changes in the structure of the specific fish farming community. The high rate of return on investment in aquaculture has attracted number of investors who tend to have a more advanced and scientific tools than the traditional farmers (FAO 2010). However, to ensuring a continuous availability and success of rearing fish production in semi-intensive aquaculture systems in earthen ponds, the implementation of the new, simple and adaptable technology targeting small-scale/middle level farmers and investors is essential step. The 
traditional methods, such as manual broadcasting or unloading the feed in specific place by aquafarmers in different parts of the pond are not very efficient and large percentage of feed either is lost in the water or creates non-natural feeding pattern. Automation of feed distribution in fish ponds has not been studied extensively and limited amount of research has been reported. Váradi (1984) listed two major groups of feeding equipment used worldwide, stationary and mobile feeding equipment. Stationary feeding equipment was further classified into demand feeders that are controlled by the fish themselves according to their appetite, and automatic feeders, that were divided into electric, pneumatic and hydraulic-type feeders based on their energy supply. Mobile feeding equipment was also divided into two major groups, feeders distributing the feed along the side of the pond and feeding equipment applying feed from a boat. As defined fish feeders categories became clear, numerous number of automatic fish feeders are commercially available with an option for all types of bonds, from small, to large, to massive ponds. Such commercial and developed feeders designed to fulfil certain objectives and requirements with added advantages such as a detachable hopper to accommodate various sizes of hopper according to user's requirement. It was also designed to have adjustable height, speed, and opening angle to accommodate different sizes of fish tanks and ponds, as well as provide a mobile fish feeder with pneumatic system for safety reasons. (Chang et al 2005, Velazquez and Martinez 2005). More advanced mechanical systems were developed to provide the food demand, and fuzzylogic control technique was used to design a controller that determines food rations, taking into account water temperature and dissolved oxygen conditions, according to fish age and body weight. The final control output is the food quantity, represented by the feeding percentage that should be provided in each feeding time; this feeding percentage is converted to the food dosage time when the feeder system must provide food (Papandroulakis et al 2000, Castañeda-Miranda et al 2006, Soto-Zarazúa et al 2010). However, for smaller ponds or lightly stocked ponds, commercial automatic feeders are a little expensive and can be overkill. They will also add to the energy bill if you choose a non-solar powered device and will need to be properly secured and checked regularly (Pond Informer 2018). For smallscale to medium size ponds, a simple energy-free automatic fish feeder was designed and fabricated, the feeder consisted of a rotating cycle wheel mounted on a slotted angle iron frame, feed boxes, trip arm, water tank and a float arrangement. The feed material can be discharged into the pond by moving the trip arm which is controlled by float rests on the water surface stored in a small tank and gradually descends due to discharging water in the tank. The unit can be set for desired number of applications of feed at desired time intervals (Chandra 1996). Also, Yeoh et al (2010) designed and tested a distribution device to overcome labour problems in the industry and introduce a semi-automatic process in the aquaculture industry. It has the ability to dispense dried fish food in various forms such as pellets, sticks, tablets or granules into fish ponds in a controlled manner for a stipulated time by using a digital timer, and it is capable of feeding the fish in accordance with a pre-determined time schedule without the presence of an operator, and at a feeding rate of $250 \mathrm{~g} / \mathrm{min}$. Wei et al (2017) fabricated a fish feeder machine that suit small ponds with maximum storage of $5 \mathrm{~kg}$ and functioning with two DC motors. This machine able to distribute 500 grams of pellets within 90 seconds and reaches distance of 4.7 meter. The higher speed could reduce time needed and increase the distance as well. The minimum speed range for both motor is 110 and 120 rpm with same full speed range of $255 \mathrm{rpm}$. Based on previous review and introduction, the objectives of this research work is to study, develop and to evaluate the operational performance of electro-mechanical movable feed distribution unit for fish ponds. The main concept of the unit is to be easy to set-up, making it quite accessible to the everyday pond owner, and can get it installed smoothly without requiring additional knowledge of the equipment beforehand. Likewise, it can be useful for feeding fish more exact doses throughout the day, which can help with maximizing growth and health.

\section{Material and Methods}

\subsection{Fish feeder spreader}

Fish Feeder Spreader consists of a solid frame, fish feed hopper, distributing disc with spreading blades, transmission system and electrical components. The electrical components include the rotational speed motor, distribution switch box, battery, dosage bar release motor, and transmission system dc brushed motors. A plastic tank has been modified and attached to hold the fish feed as hopper with volume capacity up to $20 \mathrm{I}$ (around $25 \mathrm{~kg}$ ). Fish feeder spreader components and its arrangement are presented in Fig 1. 


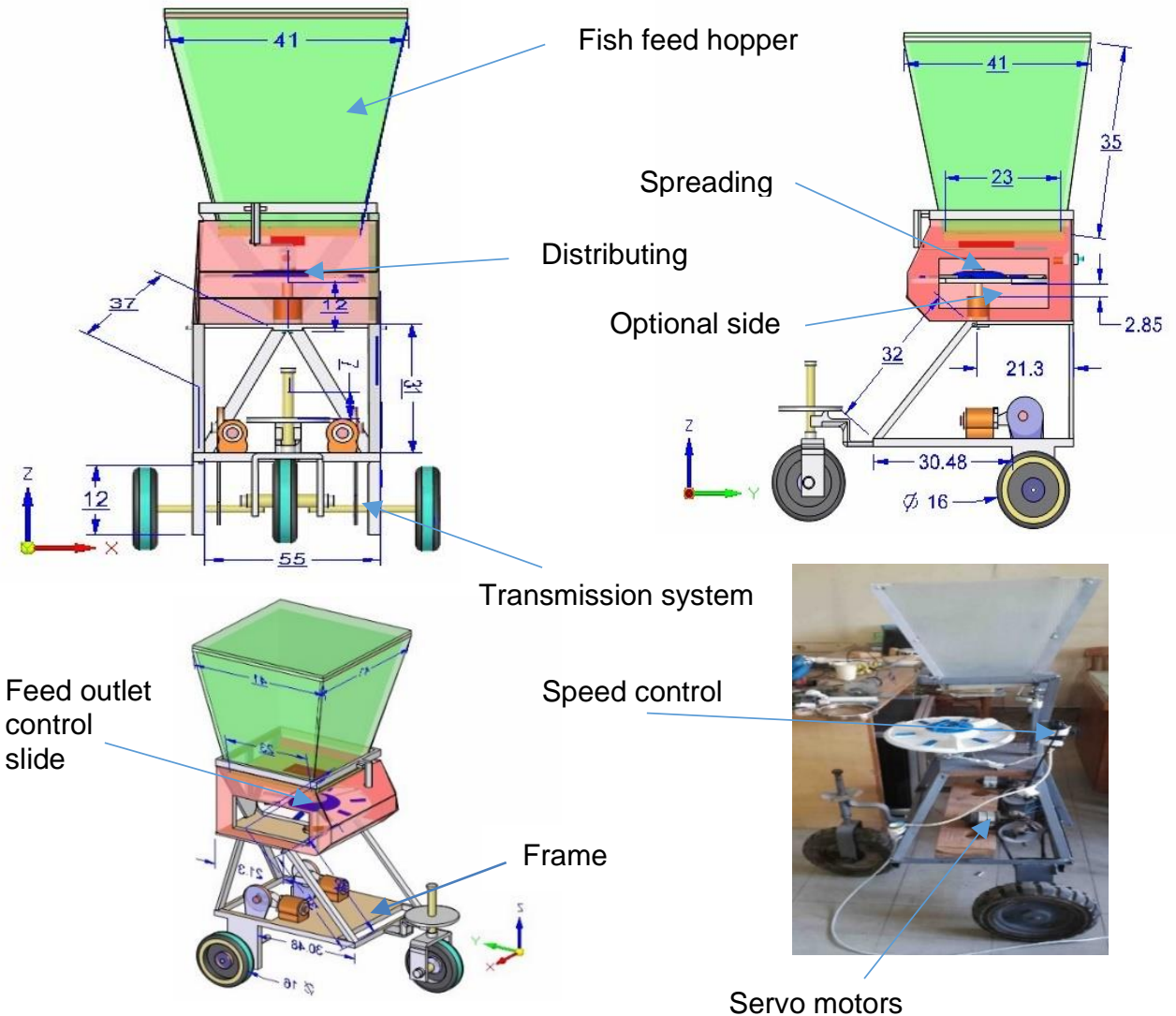

Fig 1. Major components of developed mobile fish feeder

The hopper inclination which was considered an important design factor in feed metering into distributing disc was determined using the expression $\mathrm{a}=$ $\tan ^{-1} \mu$. Where; $a=$ angle of inclination; $\mu=$ coefficient of friction. Average coefficient of friction between used hard plastic and select fish feed was 0.36 and then angle of $19.8^{\circ}$ was used to design the attached hopper.

\subsection{Distributing disc}

$330 \mathrm{~mm}$ diameter distributing disc impeller was used with 3 spreading blades $20 \mathrm{~mm}$ height and additional 6 smaller spreading blades distributed equally along with the disc perimeter for more even distribution of fish feed Fig 2. The distribution disc is being rotates with AHR- $4220 \mathrm{~V} / 1 \mathrm{~mA} / 50 \mathrm{~Hz}-60 \mathrm{~Hz}$ motor which provides rotational speed from 1000 to $1250 \mathrm{rpm}$.

\subsection{Transmission system}

Two direct current brushed motors were used to provide the distributer unit with required motion when it is needed. The main function of power transmission is to transmit the motion from direct current brushed motor which is (12 Voltage, 150 watt and 4000 r.p.m) to the frame wheels by simple gear box. The ground wheels which have been used with the developed distributer had $160 \mathrm{~mm}$ as diameter. The horizontal distance between the wheel centerlines was $450 \mathrm{~mm}$. While, the base distance between the front wheel and rear wheels axis was $650 \mathrm{~mm}$. a gear box included two different speed reduction ratio to provide 1 to $1.6 \mathrm{~m} / \mathrm{s}$ forward speeds. All transmission motors and their attached gear boxes were located on a metal and wooden frame. The front wheel was kept directing the machine only Fig $\mathbf{3}$. However, an operating person is needed to control the turnover and to start/stop the developed fish feeder. 


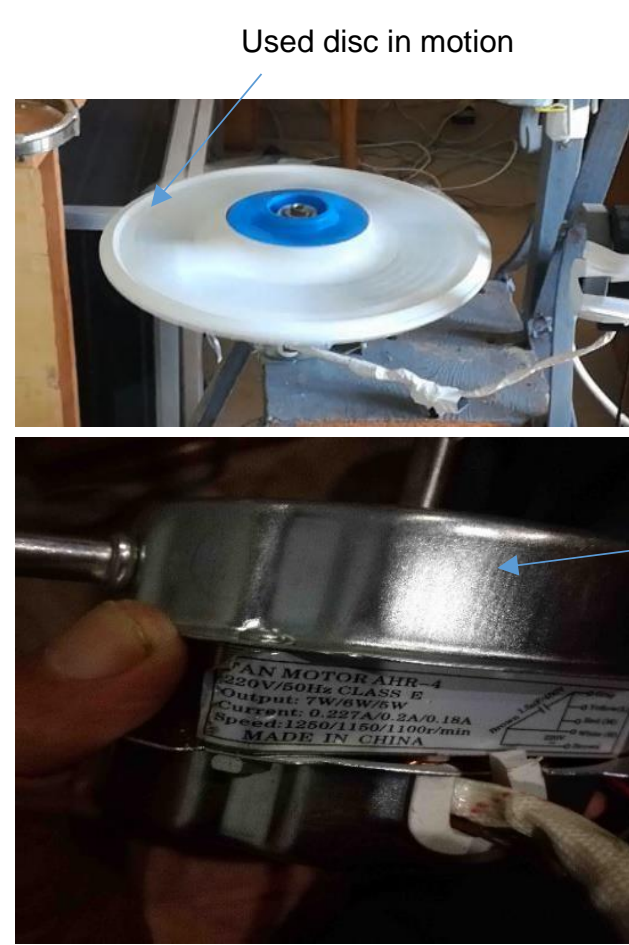

Spreading blades (spreading fins)

Fig 2. Distributing disc and its spreading blades

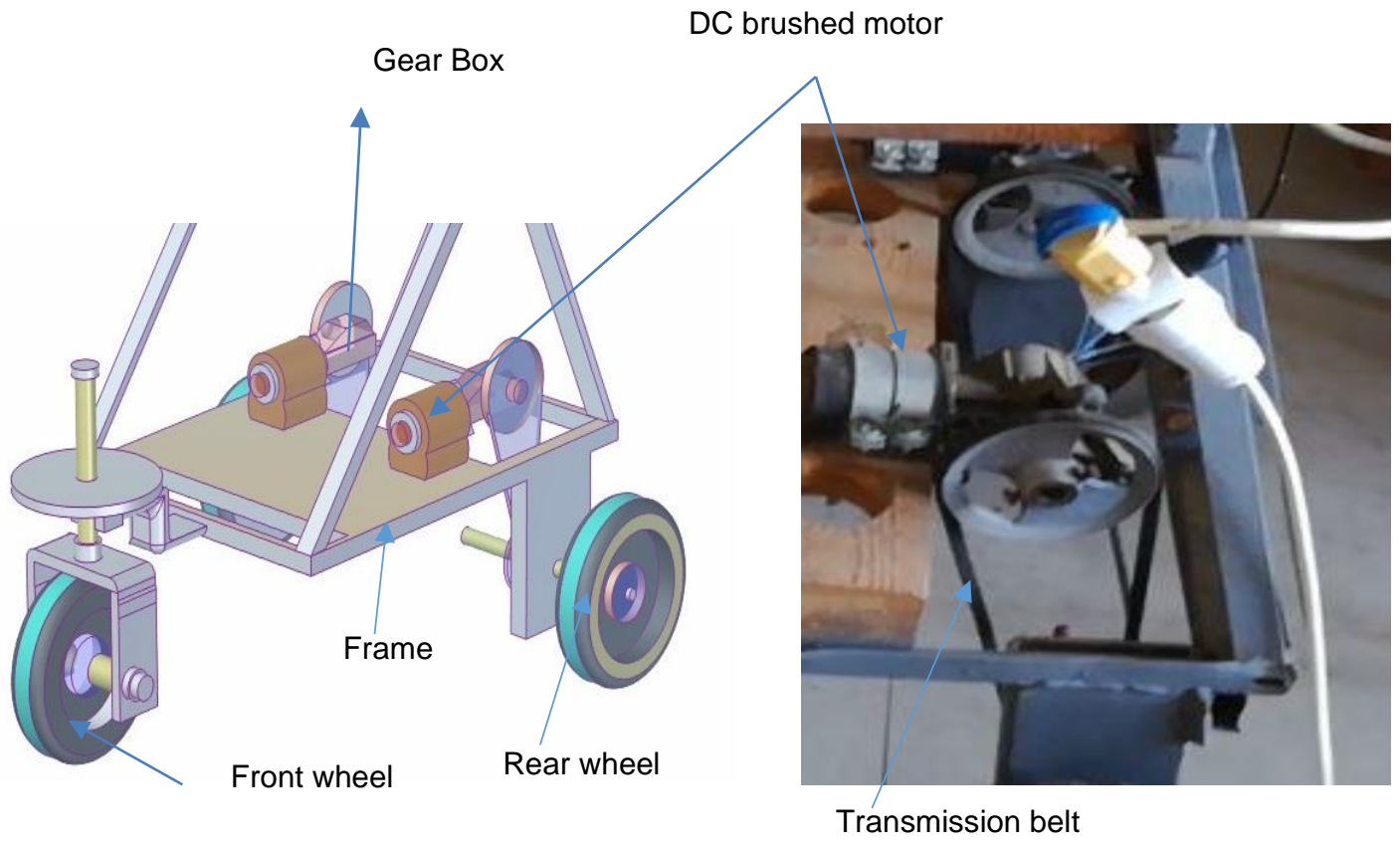

Fig 3. Arrangement of transmission system 


\subsection{Feed rate mechanism}

49TYD-500 Synchronous 5 RPM AC220/240V AC Motor was used to move the dosage bar release gate just below the hopper. The motor provided motion in two controlled horizontal directions with angle up $120^{\circ}$ degree to control and release the required amount of fish feed Fig 4. Dosage bar release gate is connected to the AC motor through a vertical fixed steel arm, when the AC motor moves, the connected arm start to move two in two directions. The distances that the release gate moves is proportional with the horizontal angel that motor achieve. When dosage bar release gate moves horizontally, it comes under the hopper release gate to close it fully, half, or partially as needed to control the feed rate.

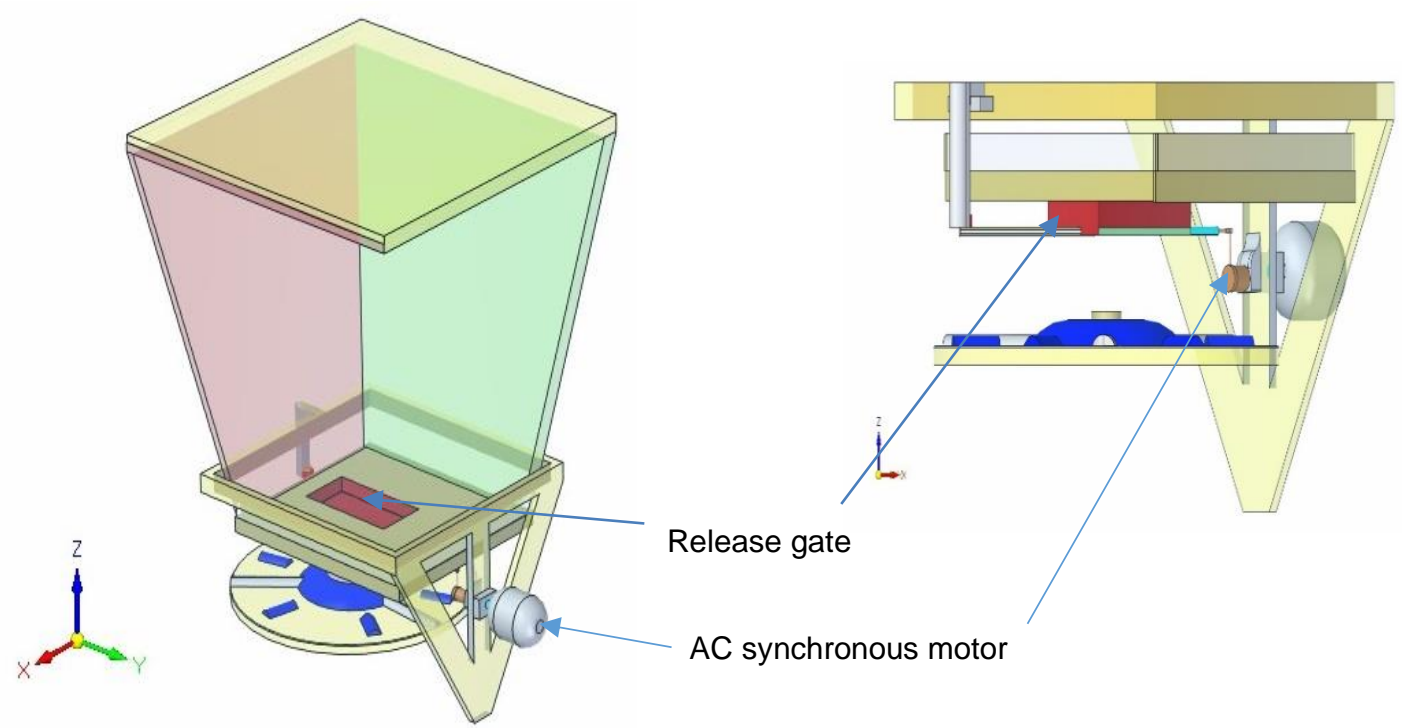

Fig 4. Delivered feed rate mechanism

\subsection{Electrical control unit}

In general, the machine is battery-operated. Electrical control unit controls and regulates the speed of the spreading disc and it used to close and open gate which is locating below the hopper too. Main components of the electrical control unit included; derive motor, speed sensor, distribution switch box, and battery cable. Technical data are presented in Table 1.
Table 1. Distributor' electrical unit

\begin{tabular}{|c|c|}
\hline Operating voltage, $\mathbf{~}$ & $\mathbf{1 2 - 2 4}$ \\
\hline Fuse, A & 25 \\
Power of driver motor & 60 \\
(spreading disc), W & \\
Power of agitator, W & 150 \\
Speed range, rpm & 500 to 1250 \\
Power consumption of & Start up to $25-$ normal \\
motor, A & operation up to 13 \\
\hline
\end{tabular}




\subsection{Study Sites, experiments variable and proce- dures}

Stationery mode experiments conducted in free area of concrete pavements and flat level sites near Dept., of Agricultural Engineering, Kafrelsheikh University during year 2019 to analyze and evaluate the distribution pattern of a newly manufactured fish feed distributer. The distribution pattern is not correlated to floor type. Different fish feed types, spreading disk rotational speeds, and feed outlet control slide setting have been chosen to determine the distribution pattern. Analysis and evaluation of distribution pattern of fish feed done under two different spreading disk rotational speeds of 1000 and 1250 rpm (17.3 and $21.6 \mathrm{~ms}^{-1}$ ), two feed outlet control slide settings for fish feed rate and three different fish feed types Table 2 and Fig 5. The experimental variable are listed in Table $\mathbf{3}$ where feed outlet control slide settings were adjusted manually by control arm attached to AC synchronous motor to open only quarter of the outlet opening as setting 1 and open half of the outlet opening as setting 2 . Distribution pattern have been tracked using catching trays (from 14 to 18 trays with $1 \times 0.5 \mathrm{~m}$ length and width respectively) with grid baffles to calculate the density of the distributed fish feed and the rate of application to validate the spreading pattern too. Total amounts of distributed fish feed were measured for 2 minutes operating time. Percentage of differences on both sides for the amount distributed by the distributer was calculated using the below equation:

$$
D=\frac{X_{R}-X_{L}}{X_{R}}
$$

Where; $D=$ Percentage of differences, \%; $X_{R}=$ Weight of material collected from right trays, g.; and $X_{L}=$ Weight of material collected from left trays, $g$.

Table 2. Specification of fish feed used in experiments

\begin{tabular}{|c|c|c|c|}
\hline Feed & Type 1 & Type 2 & Type 3 \\
\hline Main Components & $\begin{array}{c}\text { Protein } 40 \% \text {, Fat } 8 \% \text {, } \\
\text { Calcium } 1.5 \% \text {, Total P } \\
1.5 \% \text {, Ash } 12 \%\end{array}$ & $\begin{array}{c}\text { Protein } 35 \% \text {, Fat } 6 \% \text {, } \\
\text { Calcium 1.5\%, Total P } \\
1.5 \% \text {, Ash } 12 \%\end{array}$ & $\begin{array}{l}\text { Protein } 30 \% \text {, Fat } 8 \% \text {, Calcium } \\
1.5 \% \text {, Total P 1.5\%, Ash } 12 \%\end{array}$ \\
\hline Vitamins State & $\begin{array}{l}\text { Vitamin A } 18.000 \\
\text { IU/KG, vitamin D } 2.700 \\
\text { IU/KG, vitamin E: } 280 \\
\text { MG/KG, vitamin CE: } \\
200 \text { MG/KG, digestible } \\
\text { coefficients: } 90 \%-95 \% \\
\end{array}$ & $\begin{array}{c}\text { Vitamin A } 18.000 \mathrm{IU} / \mathrm{KG} \text {, } \\
\text { vitamin D } 2.700 \mathrm{IU} / \mathrm{KG} \text {, } \\
\text { vitamin } \mathrm{E}: 280 \mathrm{MG} / \mathrm{KG} \text {, } \\
\text { vitamin } \mathrm{CE}: 200 \mathrm{MG} / \mathrm{KG} \text {, } \\
\text { digestible coefficients: } \\
90 \%-95 \%\end{array}$ & $\begin{array}{c}\text { Vitamin A } 18.000 \mathrm{IU} / \mathrm{KG} \text {, } \\
\text { vitamin D } 2.700 \mathrm{IU} / \mathrm{KG} \text {, } \\
\text { vitamin } \mathrm{E}: 280 \mathrm{MG} / \mathrm{KG} \text {, } \\
\text { vitamin CE: } 200 \mathrm{MG} / \mathrm{KG} \text {, } \\
\text { digestible coefficients: } \\
90 \%-95 \%\end{array}$ \\
\hline Sizes, mm & $1-2$ & $2-3$ & $4-5$ \\
\hline Bulk density, $\mathrm{kg} \mathrm{m}^{-3}$ & 530 & 720 & 800 \\
\hline
\end{tabular}

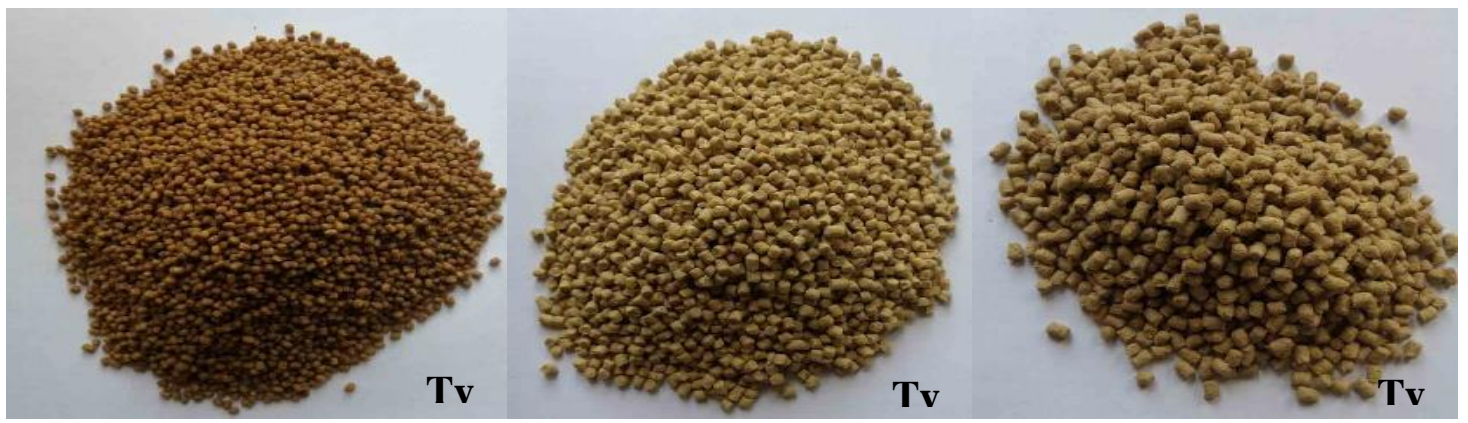

Fig 5. Three different fish feed types used in current study 
Table 3. Study experimental variable

\begin{tabular}{|c|c|c|}
\hline \multirow{4}{*}{ Fish feed Type 1} & \multirow{2}{*}{$\begin{array}{l}\text { Spreading disk rotational } \\
\text { speed (1000 rpm) }\end{array}$} & $\begin{array}{l}\text { Outlet slide settings } 1 \text { : open only quarter } \\
\text { of the outlet opening }\end{array}$ \\
\hline & & $\begin{array}{l}\text { Outlet slide settings } 2 \text { : open only half of } \\
\text { the outlet opening }\end{array}$ \\
\hline & \multirow{2}{*}{$\begin{array}{l}\text { Spreading disk rotational } \\
\text { speed (1250 rpm) }\end{array}$} & $\begin{array}{c}\text { Outlet slide settings } 1 \text { : open only quarter } \\
\text { of the outlet opening }\end{array}$ \\
\hline & & $\begin{array}{l}\text { Outlet slide settings } 2 \text { : open only half of } \\
\text { the outlet opening }\end{array}$ \\
\hline \multirow{4}{*}{ Fish feed-Type 2} & \multirow{2}{*}{$\begin{array}{l}\text { Spreading disk rotational } \\
\text { speed (1000 rpm) }\end{array}$} & $\begin{array}{l}\text { Outlet slide settings } 1 \text { : open only quarter } \\
\text { of the outlet opening }\end{array}$ \\
\hline & & $\begin{array}{l}\text { Outlet slide settings } 2 \text { : open only half of } \\
\text { the outlet opening }\end{array}$ \\
\hline & \multirow{2}{*}{$\begin{array}{l}\text { Spreading disk rotational } \\
\text { speed (1250 rpm) }\end{array}$} & $\begin{array}{l}\text { Outlet slide settings } 1 \text { : open only quarter } \\
\text { of the outlet opening }\end{array}$ \\
\hline & & $\begin{array}{l}\text { Outlet slide settings } 2 \text { : open only half of } \\
\text { the outlet opening }\end{array}$ \\
\hline \multirow{4}{*}{ Fish feed-Type 3} & \multirow{2}{*}{$\begin{array}{l}\text { Spreading disk rotational } \\
\text { speed (1000 rpm) }\end{array}$} & $\begin{array}{l}\text { Outlet slide settings } 1 \text { : open only quarter } \\
\text { of the outlet opening }\end{array}$ \\
\hline & & $\begin{array}{c}\text { Outlet slide settings } 2 \text { : open only half of } \\
\text { the outlet opening }\end{array}$ \\
\hline & \multirow{2}{*}{$\begin{array}{l}\text { Spreading disk rotational } \\
\text { speed (1250 rpm) }\end{array}$} & $\begin{array}{l}\text { Outlet slide settings } 1 \text { : open only quarter } \\
\text { of the outlet opening }\end{array}$ \\
\hline & & $\begin{array}{c}\text { Outlet slide settings } 2 \text { : open only half of } \\
\text { the outlet opening }\end{array}$ \\
\hline
\end{tabular}

\section{Result and Discussion}

3.1 Effect of spreading disk rotational speed and feed outlet control slide settings (feed rates) on the distribution pattern and density of fish feed type one

Distribution pattern and density of fish feed type 1 (sizes from 1 to $2 \mathrm{~mm}$ and average bulk density of $530 \mathrm{~kg} \mathrm{~m}^{-3}$ ) was good and covered an area of $7 \times 7$ $\mathrm{m}$ ( $6 \mathrm{~m}$ as an effective swath width) and an area of $8 \times 8 \mathrm{~m}(7 \mathrm{~m}$ as an effective swath width) for spreading disk rotational speed 1000 and 1250 rpm respectively. Feed distribution was uniform and it is achievable with outlet slide setting that allow quarter of the outlet opening Fig 6. However, there was variation on distribution of feed material type 1 in both sides of the developed prototype by 8.4 and $14.7 \%$ for disk rotational speed $1000 \mathrm{rpm}$ and $1250 \mathrm{rpm}$ respectively. Higher disk rotational speed increased the uneven distribution of feed material, that is may be due to the longer distances that material moved to. The total amounts of distributed fish feed type 1 were 9823 and $11634 \mathrm{~g}$ with 4911 and $5817 \mathrm{~g} / \mathrm{min}$ distribution rate for the two rotational speed 1000 rpm and $1250 \mathrm{rpm}$ respectively. 


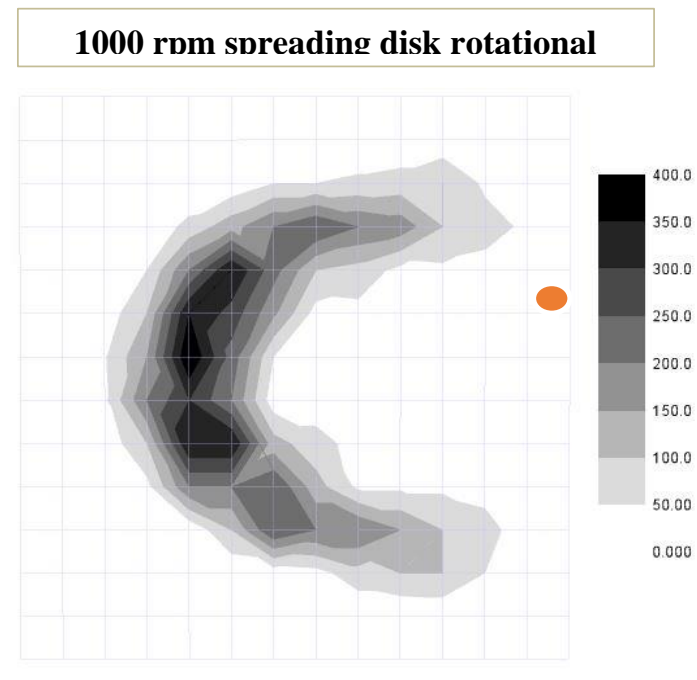

$1250 \mathrm{rbm}$ sbreading disk rotational

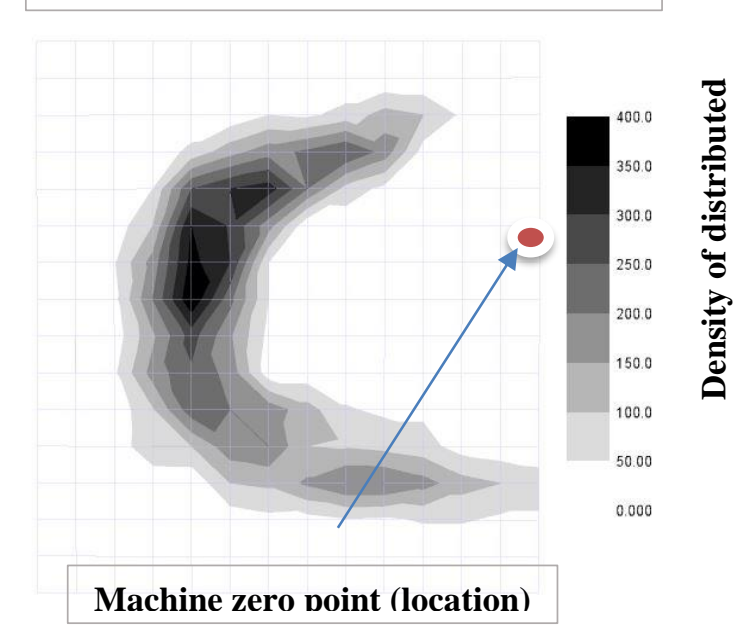

Fig 6. 3D visualization of fish feed type 1 distribution pattern and density under 1000 and $1250 \mathrm{rpm}$ spreading disk rotational speed and outlet slide settings 1 (only quarter of the outlet opening)

Using the second outlet slide settings to open half of the outlet opening ascertain the increase in amount distributed for both disc rotational speeds. The total amounts of distributed fish feed type 1 were 20168 and $20358 \mathrm{~g}$ with 10084 and 10179 $\mathrm{g} / \mathrm{min}$ distribution rate for the two rotational speed $1000 \mathrm{rpm}$ and $1250 \mathrm{rpm}$ respectively. Variation on distribution of feed material type 1 in both sides of the developed prototype by 6.4 and $12.3 \%$ for disk rotational speed $1000 \mathrm{rpm}$ and $1250 \mathrm{rpm}$ respectively. Distribution pattern of fish feed type 1 was better in case of $1000 \mathrm{rpm}$ disc rotational speed than the higher speed, where the distributed material was concentrated along with the distribution bath Fig 7.

3.2 Effect of spreading disk rotational speed and feed outlet control slide settings (feed rates) on the distribution pattern and density of fish feed type two

Feed distribution uniformity for feed type 2 was much better compare to the distribution pattern of feed type. Where, there was variation on distribution of feed material type 2 in both sides of the developed prototype by 3.5 and $3.11 \%$ for disk rotational speed $1000 \mathrm{rpm}$ and $1250 \mathrm{rpm}$ respectively under outlet slide settings 1 Fig 8 . Even with outlet slide settings 2 (only half of the outlet opening), distribution of feed material type 2 in both sides of the developed prototype was better and recorded 2.21 and $2.61 \%$ for disk rotational speed $1000 \mathrm{rpm}$ and 1250 rpm respectively Fig 9 . The total amounts of distributed fish feed type 2 were 10062 and 11248 $\mathrm{g}$ with 5031 and $5624 \mathrm{~g} / \mathrm{min}$ distribution rate for the two rotational speed $1000 \mathrm{rpm}$ and $1250 \mathrm{rpm}$ respectively under outlet slide settings 1 . Under setting 2, The total amounts of distributed fish feed type 2 were 20817 and $19407 \mathrm{~g}$ with 10409 and 97035 $\mathrm{g} / \mathrm{min}$ distribution rate for the two rotational speed $1000 \mathrm{rpm}$ and $1250 \mathrm{rpm}$ respectively. Coverage

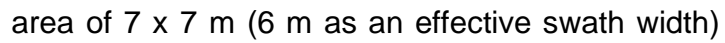
and an area of $8 \times 8 \mathrm{~m} \mathrm{(7} \mathrm{m} \mathrm{as} \mathrm{an} \mathrm{effective} \mathrm{swath}$ width) for spreading disk rotational speed 1000 and 1250 rpm respectively under outlet slide settings 1 . Under outlet slide settings 2, coverage area of $7 \times 7$ $\mathrm{m}$ ( $6.5 \mathrm{~m}$ as an effective swath width) and an area of $8 \times 8 \mathrm{~m} \mathrm{(7} \mathrm{m} \mathrm{as} \mathrm{an} \mathrm{effective} \mathrm{swath} \mathrm{width)} \mathrm{for}$ spreading disk rotational speed 1000 and $1250 \mathrm{rpm}$ respectively.

3.3 Effect of spreading disk rotational speed and feed outlet control slide settings (feed rates) on the distribution pattern and density of fish feed type three

Distribution pattern and density of fish feed type 3 (sizes from 4 to $5 \mathrm{~mm}$ and average bulk density of $800 \mathrm{~kg} \mathrm{~m}^{-3}$ ) completely was uneven. The bigger feed size gave up-normal distribution behaviour when used with the prototype. The differences and variation of distribution of feed material type 3 in 
both sides of the developed prototype ranged from 34 to $40 \%$ for all setting and disc rotational speed. In addition, the material of fish feed type 3 created a blocking conditions and there was difficulties to move from the hopper to the rotating distribution disc. Fig 10 shows the differences in fish feed

\section{0 rpm spreading disk rotational speed}

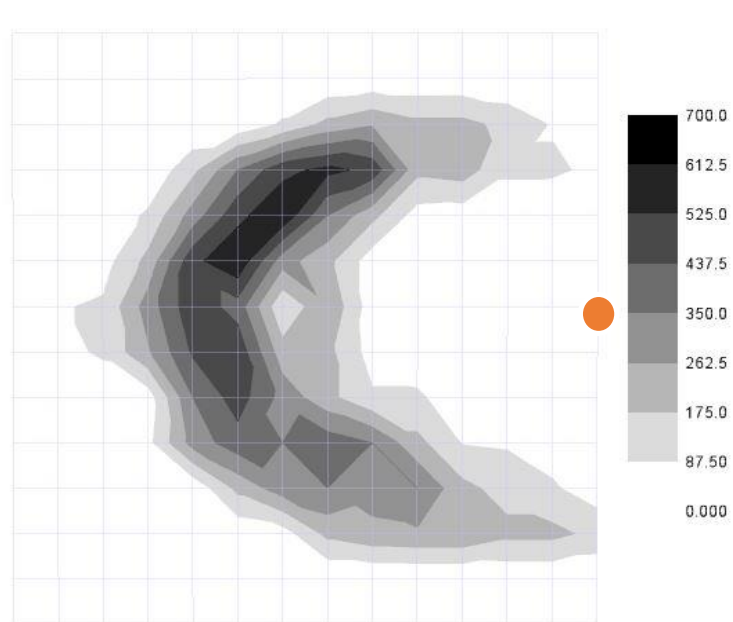

amount distributed along both sides of the developed prototype, where the most of feed materials were located in the left side. That is clear that using fish feed material with size bigger than $4 \mathrm{~mm}$ will lead to uneven distribution using current developed prototype.

Fig. 7. 3D visualization of fish feed type 1 distribution pattern and density under 1000 and 1250 rpm spreading disk rotational speed and outlet slide settings 2 (only half of the outlet opening)

\section{$1000 \mathrm{rpm}$ spreading disk rotational speed}

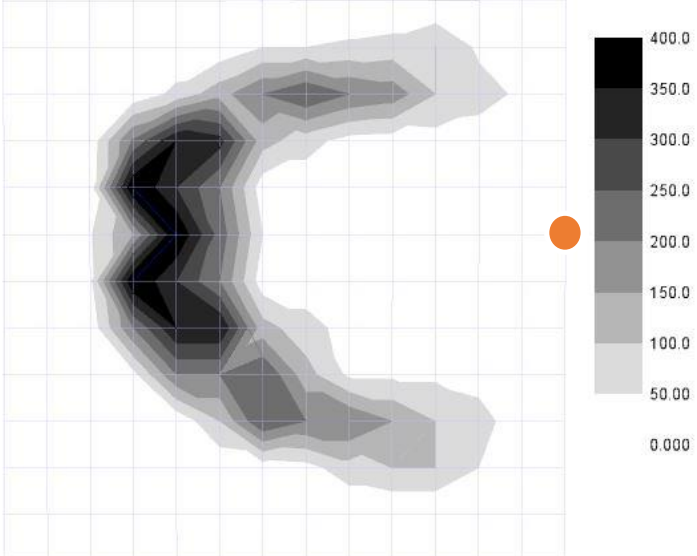

\section{$1250 \mathrm{rpm}$ spreading disk rotational speed}

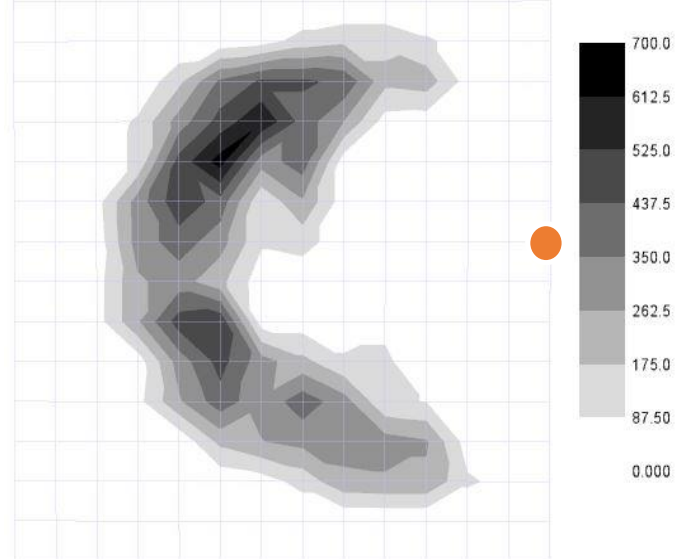

Fig 8. 3D visualization of fish feed type 2 distribution pattern and density under 1000 and 1250 rpm spreading disk rotational speed and outlet slide settings 1 (only quarter of the outlet opening) 

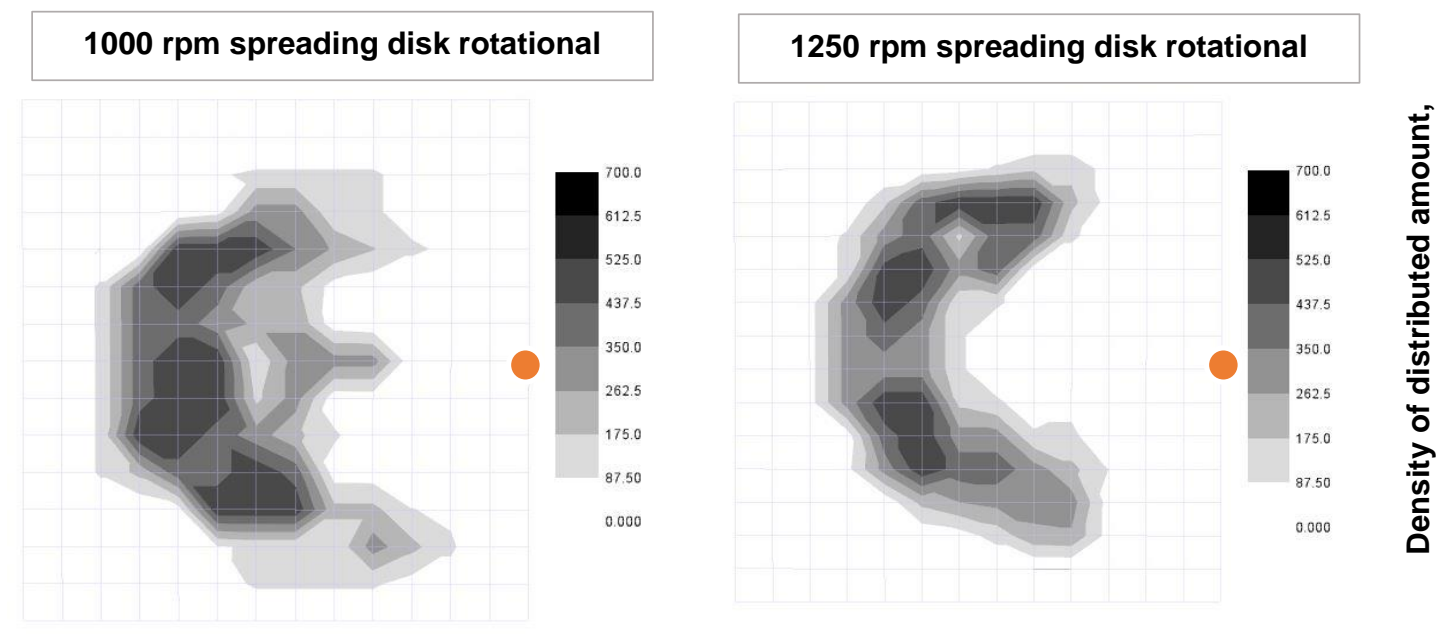

Fig 9. 3D visualization of fish feed type 2 distribution pattern and density under 1000 and 1250 rpm spreading disk rotational speed and outlet slide settings 2 (only half of the outlet opening)

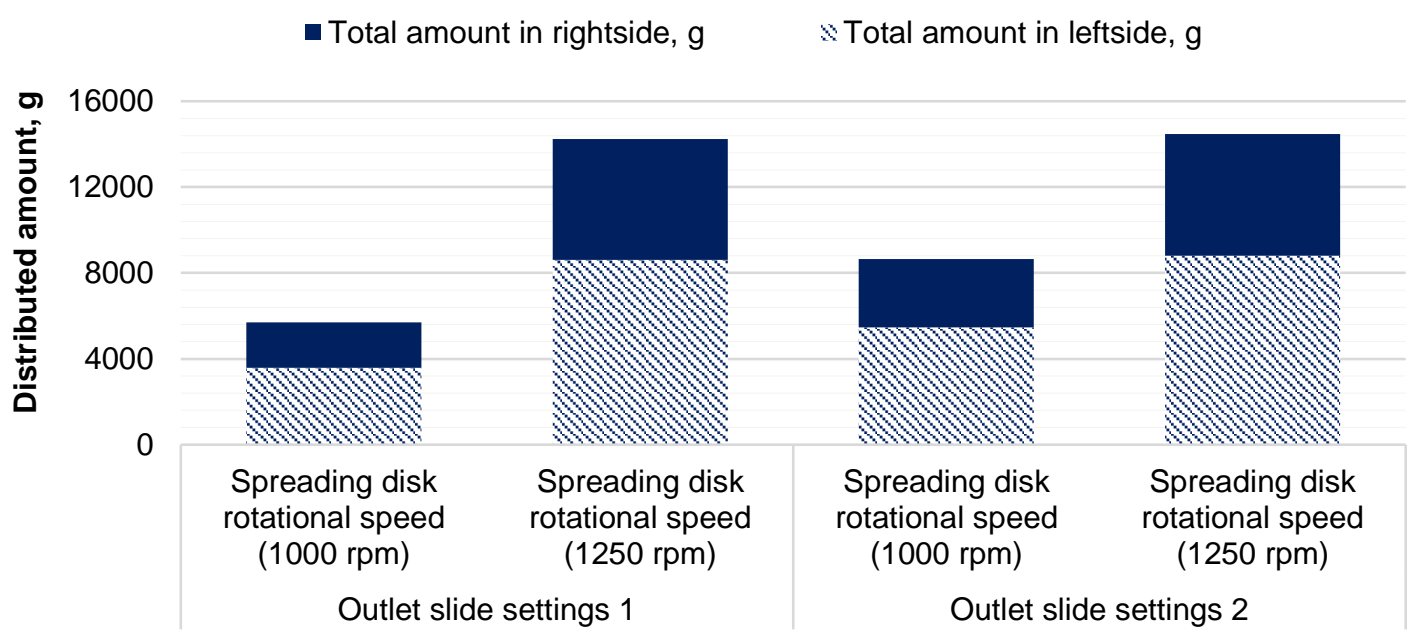

\section{Study variables}

Fig 10. Differences in amount fish feed distributed along both sides of the developed prototype

\section{Conclusion}

Developed prototype showed good performance in distributing fish feed with size from 1 to $3 \mathrm{~mm}$, where best distribution pattern was achieved by using fish feed size from 2 to $3 \mathrm{~mm}$ with both recommended disc rotational speed 1000 and $1250 \mathrm{rpm}$. The prototype can be used to distribute fish feed material either with outlet slide setting 1 (open only quarter of the outlet opening) or outlet slide settings 2 (open only half of the outlet opening), and in both cases the developed prototype can achieve good distribution pattern. The simple concept and available prototype material make it very affordable and any farmer can use it for the small-scale fish bonds to minimize the distribution time and achieve good distribution pattern with saving efforts when perform the operation manually. However, it is recommended to study and to develop further prototypes for wider commercial use and to be suitable for different feed sizes. 


\section{References}

Castañeda-Miranda, R; Ventura-Ramos, EJ; Peniche-Vera, RR; Herrera-Ruiz, G (2006) Fuzzy greenhouse climate control systems based on a field programmable gate array. Biosyst Eng 94, 165-177.https://doi:10.1016/j.biosystemseng.2006.02.012.

Chandra, BM (1996) Performance of Hawaii-type automated fish feed dispenser. Aquac Eng 15, 8190. https://doi:10.1016/0144-8609 (95)00011-9.

Chang, CM; Fang, W; Jao, RC; Shyu, CZ; Liao, IC (2005) Development of an intelligent feeding controller for indoor intensive culturing of Eel. Aquacultural Engineering 32, 343-353.

https://doi:10.1016/j.aquaeng.2004.07.004.

FAO (2010) National Aquaculture Sector Overview: Egypt. Fisheries and. Aquaculture Department. Food and Agric. Organization of the United Nations, Rome. Available at: http://www.fao.org/fishery/countrysector/naso_egypt/en

FAO (2018) The State of World Fisheries and Aquaculture - Meeting the sustainable development goals. Food and Agriculture Organization of the United Nations, Rome. Available at: www.fao.org/3/i9540en/I9540EN.pdf.

Linn (2020) Water is our element. Feed Fish Reliably. Aqua Technology Catalogue. LINN Gerätebau GmbH. Lennestadt (Oedingen), Germany, pp. 1-2. https://www.linn.eu/linn-fish-feeding/files/assets/common/downloads/publication.pdf.

Papandroulakis, N; Markakis, G; Divanach, P; Kentouri, M. (2000) Feeding requirements of sea bream (Sparusaurata) larvae under intensive rearing conditions. Development of a fuzzy logic controller for feeding. Aquac Eng 21, 285-299. https://doi:10.1016/S0144-8609(99)00036-9.
Pond Informer, (2018) The Best Automatic Pond Fish Feeder (Reviews \& Costs). Pond Informer, Amazon Services LLC Associates Program. Available at: https://pondinformer.com/best-automatic-pondfish-feeder/

Soliman, N; Yacout, D (2016) Aquaculture in Egypt: status, constraints and potentials. Aquaculture International. 24 p. http://dx.doi.org/10.1007/s10499016-9989-9.

Soto-Zarazúa, GM; Rico-García, E; Ocampo, R; Guevara-Gonza'lez; Gilberto Herrera-Ruiz, RG (2010) Fuzzy-logic-based feeder system for intensive tilapia production (Oreochromis niloticus). Aquaculture International 18, 379-391. https://doi.org/10.1007/s10499-009-9251-9.

Váradi, L (1984) Mechanized Feeding in Aquaculture. Inland Aquaculture Engineering. United Nations Development Programme Food and Agriculture Organization of the United Nations, Rome. Available at: http://www.fao.org/docrep/x5744e/x5744e0k.htm

Velazquez, M; Martinez, FJ (2005) Design and testing of a faeces-collecting device for fish digestibility studies using demand or automatic feeding. Aquacultural Engineering 33, 126-134. https://doi.org/10.1016/j.aquaeng.2004.12.004.

Wei, HC; Salleh, SMA; Ezree, M.; Zaman, I; Hatta, MH; Zain, Md; Mahzan, BA; Rahman, SMNA; Mahmud, WAW (2017) Improvement of automatic fish feeder machine design. International Conference on Materials Physics and Mechanics. IOP Conf. Series: J of Physics: Conf Series 914 (2017) $012041 . \quad$ https://iopscience.iop.org/article/10.1088/1742-6596/914/1/012041/pdf.

Yeoh, SJ; Taip, FS; Endan, J; Talib, RA; Siti Mazlina, MK (2010) Development of Automatic Feeding Machine for Aquaculture Industry Pertanika J Sci Technol 18, 105-110. Available at: https://core.ac.uk/download/pdf/153797419.pdf. 


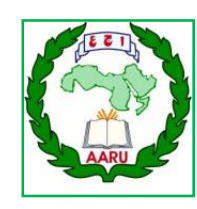

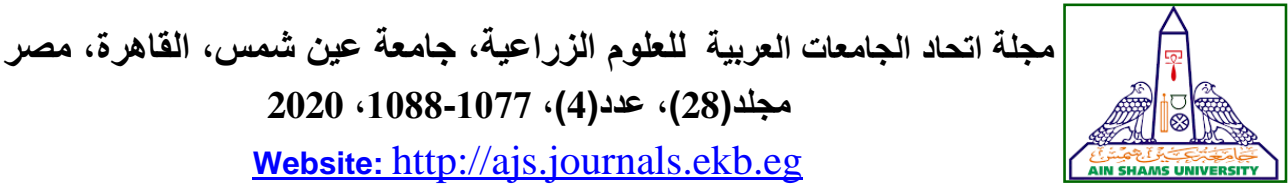

تطوير مغذي أسماك متحرك كهروميكانيكي صغير الحجم

رشاد عزيز حجازي" - عاطف محمد السباعي - منى مرجان قاسم

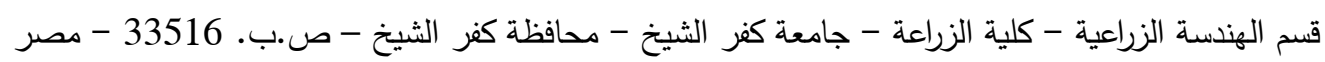

*Corresponding author: rashad.hegazy@agr.kfs.edu.eg

Accepted 1 November, 2020

في توزيع مادة التغذية من النوع 1 في كلا جانبي النموذج

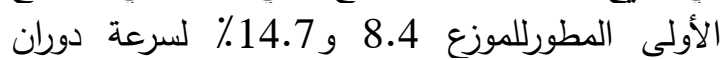

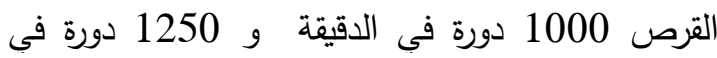

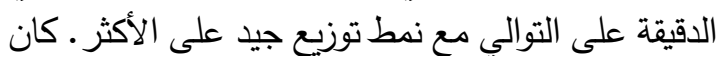

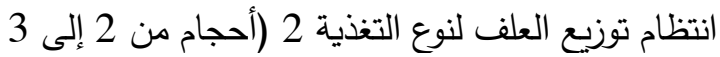

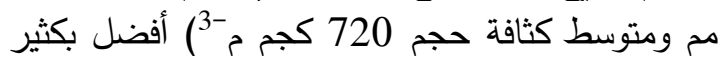

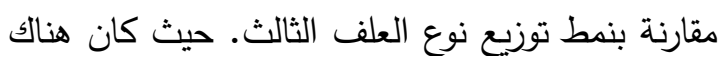

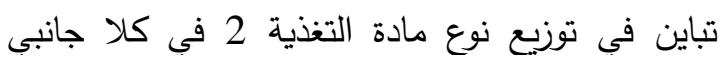

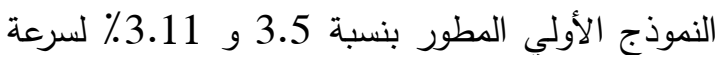

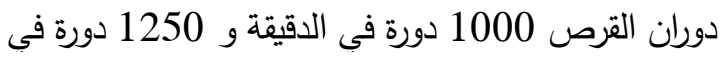
الدقيقة على التوالى في ظل إعدادات شريحة تحديد الكمية

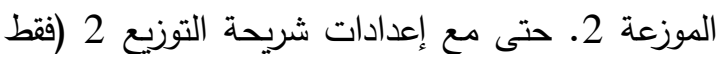

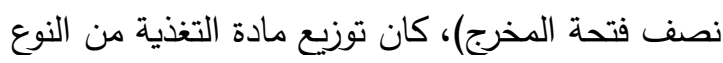

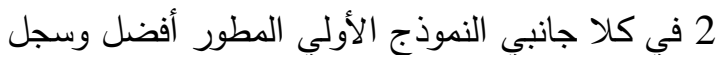

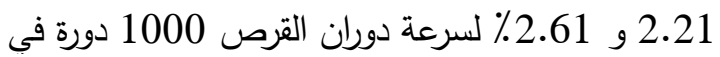

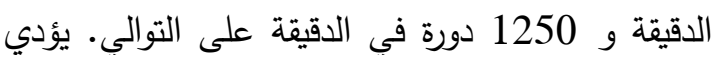

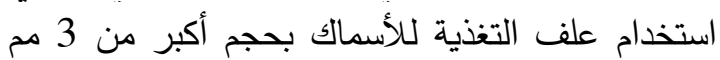
إلى توزيع غير متساو باستخدام النموذج الأولى المطور

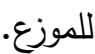

الهدف من هذه الدراسة هو تطوير واختبار مغذي

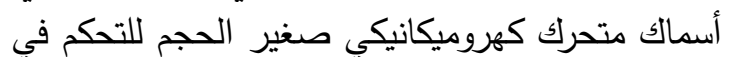

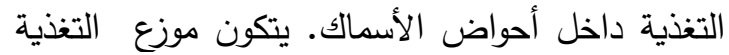

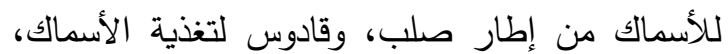

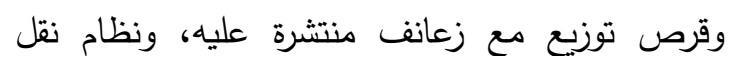

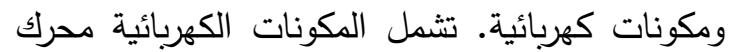

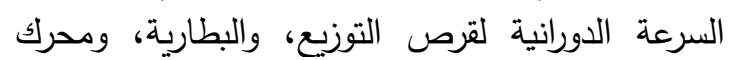
تحرير كمية العلف الموزع، ومحركات DC لنظام النقل.

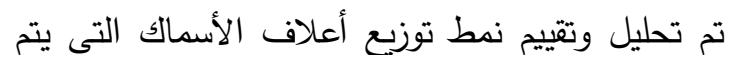
إجراؤها في ظل سرعتين مختلفتين لقرص الانتشار هما

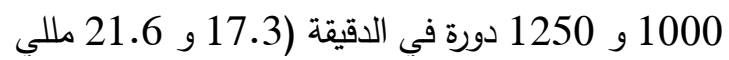
ثانية-1)، وإعدادان لشريحة التحكم في مخرج التئة التغذية

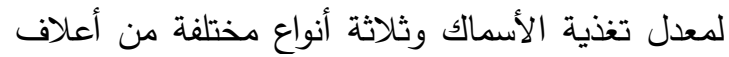

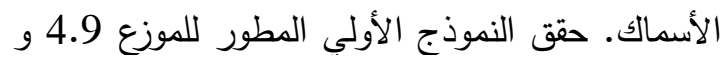

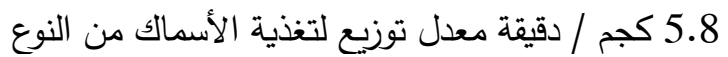

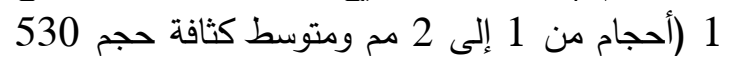

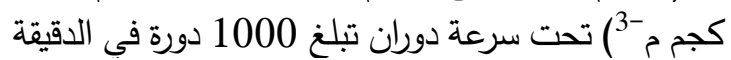
و 1250 دورة في الدقيقة على التوالي. كان الاختلاف تلف دورة 